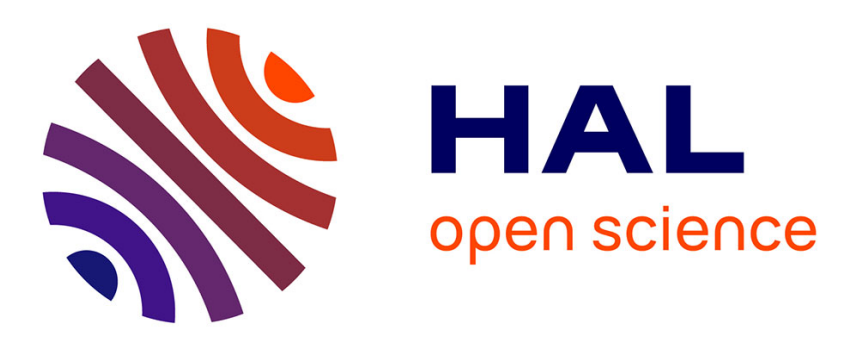

\title{
Distribution of duricrusted bauxites and laterites on the Bamiléké plateau (West Cameroon): Constraints from GIS mapping and geochemistry
}

Mathieu Nouazi Momo, Martin Yemefack, Paul Tematio, Anicet Beauvais, Jean-Paul Ambrosi

\section{To cite this version:}

Mathieu Nouazi Momo, Martin Yemefack, Paul Tematio, Anicet Beauvais, Jean-Paul Ambrosi. Distribution of duricrusted bauxites and laterites on the Bamiléké plateau (West Cameroon): Constraints from GIS mapping and geochemistry. CATENA, 2016, 140, pp.15-23. 10.1016/j.catena.2016.01.010 . ird-01419953

\section{HAL Id: ird-01419953 \\ https://hal.ird.fr/ird-01419953}

Submitted on 20 Dec 2016

HAL is a multi-disciplinary open access archive for the deposit and dissemination of scientific research documents, whether they are published or not. The documents may come from teaching and research institutions in France or abroad, or from public or private research centers.
L'archive ouverte pluridisciplinaire HAL, est destinée au dépôt et à la diffusion de documents scientifiques de niveau recherche, publiés ou non, émanant des établissements d'enseignement et de recherche français ou étrangers, des laboratoires publics ou privés. 


\section{Spatial distribution of bauxitic duricrusted laterites on the Bamiléké} plateau (West Cameroon): constrained GIS mapping and geochemistry

3 Mathieu NOUAZI MOMO**1, Martin YEMEFACK ${ }^{2,3}$, Paul TEMATIO ${ }^{1}$, Anicet BEAUVAIS ${ }^{4}$, Jean-Paul AMBROSI $^{4}$

4

$5{ }^{1}$ University of Dschang, Faculty of Science, Department of Earth Science, PO Box 67, Dschang, Cameroon.

$6{ }^{2}$ Institute of Agricultural Research for Development (IRAD), PO Box 2067, Yaoundé, Cameroon,

$7 \quad{ }^{3}$ International Institute of Tropical Agriculture (IITA), ASB Partnership REALU Project, PO Box 2008 (Messa)

8 Yaoundé, Cameroon.

$9{ }^{4}$ Aix-Marseille Université, CNRS, IRD, CEREGE UM34, 13545 Aix-en-Provence, France.

10

11 *Corresponding author: Tel. (237) 695650828; Email: nouazimat@ yahoo.fr \& nouazi@ cerege.fr

12 Running Title: Bauxitic duricrusts on the Bamiléké Plateau 


\section{Abstract}

15 Estimation of the mineral resources potential is an important issue for most of developing countries. The 16 spatial distribution of lateritic landsurfaces and bauxite on the Bamiléké plateau (West Cameroon) has 17 been investigated with a Boolean modeling process into a GIS environment on the basis of geological 18 constraints namely elevation, rock types, landscape morphology and soil types. Field observation and 19 SRTM (Shuttle Radar Topographic Mission) data allowed the differentiation of two lateritic surfaces 20 separated by a minimum altitude difference of about $60 \mathrm{~m}$. These surfaces constrained by favorable rock 21 types, slope steepness and soil types provided a potential lateritic bauxitic area of $381 \mathrm{~km}^{2}(17.2 \%$ of the 22 total study site), which matches the current bauxitic areas and evidences a large non-explored area in the 23 north of the study site. Field validation and the integration of legacy spatial data resulted in an area of $2460.1 \mathrm{~km}^{2}$ for potential bauxitic ores, i.e. obviously duricrusted landsurfaces (with $47.8 \mathrm{~km}^{2}$ in the upper 25 surface and $12.3 \mathrm{~km}^{2}$ in the lower surface). Geochemical data (mostly $\mathrm{Al}_{2} \mathrm{O}_{3}$ wt.\%) obtained from 26 duricrust samples were treated by geostatistical methods and classical kriging interpolation to 27 discriminate between bauxitic and ferruginous laterites. This highlighted a geochemical trend from higher 28 alumina values on the upper surface (40-66 wt.\%) to lower values on the lower surface (13-44 wt.\%).

29 Finally, our study documents two indurated lateritic surfaces arranged in a staircase manner and having 30 different geochemical characteristics. The total bauxitic-rich surface is distributed in five different spots 31 throughout the study area and covers $56.2 \mathrm{~km}^{2}$, while ferruginous laterites occupy a spot of $3.9 \mathrm{~km}^{2}$. GIS 32 mapping approach of lateritic landsurfaces, accounting for reliable constraints, might be promising for 33 larger scale investigations of mineral resources in developing Countries.

34

35 Keywords: Bauxite; Boolean modeling; Kriging; Bamiléké plateau; Cameroon 


\section{Introduction}

Many Third World Countries rely mainly on their natural resources to sustain their economic development. In Cameroon, the exploitation of mineral resources has traditionally been a significant component of the economy (Ntép Gweth, 2009). However, knowledge on the real potential of these

41 resources is generally limited by a lack of geo-exploration tool required for their reliable and 42 comprehensive assessment and classification at the national-wide level. In this country, the most 43 widespread ore deposits are lateritic bauxites, representing the $6^{\text {th }}$ reserve in the world. Bauxites occur in 44 the Adamaoua and Western regions, and have been previously studied by many authors (Eno Belinga, 45 1968; Eno Belinga, 1972; Hiéronymus, 1973; Momo Nouazi et al., 2012; Morin, 1985; Nicolas and Eno 46 Belinga, 1969; Nyobe, 1987) using classical approaches of field survey and laboratory analyses. 47 Nowadays, GIS and remote sensing tools permit more accurate mapping of such resources by integrating favorable geological constraints in a GIS-based model.

Our study aimed at satisfying the practical need for supporting bauxite exploration in Cameroon with up-to-date maps, by defining the relation between bauxitic deposits and their geological environment. For this purpose, we used a GIS-modeling approach, based on a well-established procedure

52 previously tested in several studies on mineral potential assessment (Bonham-Carter, 1994; Boroushaki 53 and Malczewski, 2008; Carranza, 2002; Carranza, 2009; Carranza et al., 1999; Carranza et al., 2008; 54 Cheng and Agterberg, 1999; Guha et al., 2013; Harris et al., 2008; Harris et al., 2001; Robinove, 1989; 55 Thiart and De Wit, 2000; Thole et al., 1979; Varnes, 1974; Zadeh, 1965). The approach deals with GIS56 based geologically constrained mineral potential mapping, a multistage strategy for delineating 57 mineralized zones (Reeves et al., 1990). Multivariate and multisource geo-exploration datasets were 58 combined to enhance favorable geologic features indicative of mineral deposit (Bonham-Carter, 1994; 59 Hodgson, 1990). Our interest was thus to know via the Boolean model of Varnes (1974) and Robinove 60 (1989), whether the spatial criteria linked to the genetic environment and landscape distribution of 
61 bauxites can be used to define predictive map of bauxite occurrence for further field exploration and 62 geochemical survey.

63

64

\section{3. Methods}

83 3.1. Conceptual model of bauxite occurrence

\section{Physiography of the study area} plain in the south and west.

The study site lies between longitudes $09^{\circ} 56^{\prime}-10^{\circ} 20^{\prime} \mathrm{E}$, and latitudes $05^{\circ} 18^{\prime}-5^{\circ} 45^{\prime} \mathrm{N}$ and covers an area of $2209 \mathrm{~km}^{2}$ within the Bamiléké plateau extending between $09^{\circ} 44^{\prime}-10^{\circ} 33^{\prime} \mathrm{E}$, and $04^{\circ} 10^{\prime}-$ $05^{\circ} 56^{\prime} \mathrm{N}$ in West Cameroon (Figs. 1A and B). The main morphological features of this area is the Mount Bambouto, culminating at the altitude of $2725 \mathrm{~m}$ (Fig. 1B), which is the third most important and highest volcano of the Cameroon Volcanic Line (Déruelle et al., 1991). It covers the southern part of the West Cameroon highland between the Bamoun plateau in the east, the Grassfields in the north and the Mbô

The climate of the Bamiléké plateau is sub-equatorial, influenced by high altitudes, with 1600$2000 \mathrm{~mm}$ mean annual rainfall and $18^{\circ} \mathrm{C}-20^{\circ} \mathrm{C}$ for the mean annual temperature.

The Cameroon Volcanic Line consists of a wide Cenozoic volcanic complex extruded on the Neoproterozoic Panafrican granito-gneissic basement, which is also intruded by mafic and felsic plutons (Kwekam et al., 2010). The volcanic complex is known to be the parent material for the plateau Bamiléké bauxites. The new ${ }^{40} \mathrm{~K}-{ }^{40} \mathrm{Ar}$ geochronological data showed three main periods of volcanic activity extending from the Miocene (Burdigalian) (Marzoli et al., 1999) to the Pliocene (Nkouathio, 2006), and uncommon lava spots extending up to 0.5 My (Kagou Dongmo et al., 2010). Lavas geochemistry shows a trend extending from basanites to trachytes or phonolytes.

A conceptual and exploration model for evaluating the bauxite potential of the Bamiléké Plateau was built based on geological criteria (Carranza, 2002; De Araújo and Macedo, 2002; Hodgson, 1990; 
Reeves et al., 1990). Amongst the operators used for examining the spatial association of geological

87 features is the Boolean model, which is based on a reclassification of the input maps into only two classes

88 (Bonham-Carter, 1994; Carranza et al., 2008; Harris et al., 2001; Robinove, 1989; Thiart and De Wit,

89 2000; Varnes, 1974), i.e., the maximum and minimum evidential score classes (0 or 1). Reclassified maps

90 are combined logically according to a set of steps so-called inference network (Fig. 2), which reflects the

91 inter-relationships of processes controlling the occurrence of a geo-object and the spatial features

92 indicating the presence of this geo-object (Carranza, 2002; Carranza, 2009). Finally, the output of

93 combined evidential maps via Boolean logic modeling is a two class map; the first class represents

94 locations where all of the prospective recognition criteria are satisfied, whilst the second class represents

95 locations where at least one is unsatisfied (Carranza, 2009).

The study was carried out with ILWIS GIS software (ITC ILWIS Unit, 2001) using a three step

97 methodology including: (1) gathering spatial data into a GIS, (2) extracting spatial evidential data and

98 creating derivative maps to be used as spatial evidence of bauxite mineralization, (3) integrating the

99 spatial evidence map to create bauxitic potential map and validating the predictive map (Bonham-Carter, 100 1994).

101

102 3.2. Analysis of constraints

103

In our study, the criteria or constraints from the rock types, landscape morphology (elevation

104 ranges and slopes), and soil types were defined and linked to delineate favorable zones on the Bamiléké 105 Plateau. These zones are potentially duricrusted landsurfaces areas with alumina-rich surface materials, 106 which are characterized by deep and extremely leached soils (Hiéronymus, 1973; Momo Nouazi et al., 107 2012; Nyobe, 1987).

Lateritic bauxites are known to form mainly by chemical weathering of rocks in which low silica 109 content favors crystallization of gibbsite instead of kaolinite (Tardy, 1993). However, many other studies 110 have also described bauxite formation from a variety of parent materials including basic and acid rocks 
111 (Bildgen, 1973; Boulangé, 1984; Boulangé et al., 1997; Boulangé et al., 1996; Boulangé and Colin, 1994;

112 Chardon et al., 2006; Eno Belinga, 1972; Momo Nouazi et al., 2012; Soler and Lasaga, 2000).

113 Meanwhile, the geological substratum is an important factor contributing to the preservation of lateritic

114 bauxites from surface stripping (Boulangé, 1984). On the Bamiléké plateau, a variety of rocks derived

115 from complex magmatic and metamorphic events exist (Dumort, 1968; Kagou Dongmo et al., 2010;

116 Kwekam et al., 2010; Nkouathio et al., 2008), but the bauxites are formed exclusively upon volcanic

117 rocks (Momo Nouazi et al., 2012; Morin, 1985; Nyobe, 1987).

118 Bauxitic laterites generally occur on high elevation, low relief planation landsurface remnants

119 lying on flat or gently sloped surfaces (Grandin and Thiry, 1983; Chardon et al., 2006; Beauvais and

120 Chardon, 2013). These morphological characteristics allow localizing bauxitic laterites from altitudinal

121 levels and slope distribution (Riis and Fjeldskaar, 1992).

122 Bauxitic laterites are developed under a tropical climate that favors deep rock weathering and the 123 development in soils of a thick B-horizon resulting from lixiviation process (Boulangé and Colin, 1994; 124 Grandin and Thiry, 1983; Maignien, 1966; Pedro, 1968; Tardy, 1993). Commonly, bauxites described on 125 well-preserved landsurfaces show thickness extending up to 20 and 30 m (Grandin and Thiry, 1983; 126 Segalen, 1967). The presence or absence of the B-horizon in soils was used to determine potential areas 127 of bauxite development in the study area.

\section{4. Results}

130 4.1. Favorable constraints

\subsubsection{Favorable rock types}

Within the study site, volcanic rocks cover $64 \%$ of the total surface (Fig. 3A), comprising mainly 133 basalts (64\%), trachytes (28\%) and ignimbrites (6\%), which have been formed since 19 My covering an 134 area of $1406 \mathrm{~km}^{2}$ (Marzoli et al., 1999; Nkouathio et al., 2008). All these volcanic rocks currently show 135 evidence of deep weathering process (Tematio et al., 2004). Phonolites and volcanic ashes cover limited 
areas $(\sim 1 \%)$ on the study site. These recent volcanic rocks range from 4 My for phonolites (Nkouathio et al., 2008) to 0.48 My for volcanic ashes (Kagou Dongmo et al., 2010). The phonolites are found on elevated dykes with no evidence of weathering. Volcanic ashes are very little altered exhibiting a very thin non-differentiated profile (Tsopjio Jiomeneck et al., 2011). Taking into account all these data, 140 basalts, trachytes and ignimbrites are rock types with potential to control bauxite occurrences in the study 141 area.

\subsubsection{Favorable morphological features: elevation and slope}

On the Bamiléké plateau, legacy data and field observations have contributed to differentiate two 144 lateritic surfaces with minimum elevation of 1520 and $1580 \mathrm{~m}$ for the lower and the upper surface, 145 respectively (Fig. 3B). The $60 \mathrm{~m}$ height difference (Dh; Fig. 4) is a lithologically controlled feature marked by flow scarps separating two types of volcanic materials. These are reported on the central and 147 the western part of the study site (Fig. 4) as a limit between the Mount Bambouto lava and the surrounding shield (Nkouathio et al., 2008); and on the southeastern part by the Bangam flow scarp. The lower surface is an undulated low relief landscape with few interfluves culmunating up to about $1580 \mathrm{~m}$, corresponding mainly to the Doumbouo-Fokoué area (Fig. 3B; Fig. 4) between large remnants of the upper surface (Fig. 3B). The upper surface includes the so called Fongo-Tongo deposit, the Loung deposit

152 and the Bangam deposit (Fig. 3B; Fig. 4) and a large unexplored area in the northern part of the study site 153 (Fig. 3B), whose the maximum altitude is not actually well defined although laterites have been described 154 up to about $1900 \mathrm{~m}$.

Remnants of bauxitic surfaces on the Bamiléké plateau are most often highly dissected due to the combined effects of tectonic uplift, climate and drainage pattern (Morin, 1985), and are incised by steep

157 valleys. Landscape dissection results in two morphological features related to different incision stages.

158 The first one corresponds to isolated gently sloping interfluves ( 0 to $5^{\circ}$; Fig. $\left.3 \mathrm{C}\right)$, which are covered by 159 continuous duricrusted laterites (Fig. 5A) and limited by steep slopes up to $76^{\circ}$ (Fig. 5B). The second 160 feature corresponds to widespread elongated interfluves with convex summits showing slope classes 
ranging from 0 and $15^{\circ}$ (Fig. 3C). Well-preserved duricrusts occur on the lowest slopes, but are stripped

162 on increasing slopes steepness. This is obvious on a sequence at Doumbouo-Fokoué showing continuous

163 duricrust on the top, discontinuous duricrust on summit shoulder, and gravelly horizon on $15^{\circ}$ slopes

164 marking the lower topographic limit of the lateritic surface (Fig. 5C). Landform units and slope classes

165 derived from SRTM (Shuttle Radar Topographic Mission) data were thus potential morphological

166 features for mapping bauxitic deposits. The favorable elevation ranges delineate a surface of $685 \mathrm{~km}^{2}$ and

$167223 \mathrm{~km}^{2}$ on the upper surface and lower surface, respectively (Fig. 3B). Favorable sloping land surface

168 covers a total surface of $1702 \mathrm{~km}^{2}$ with slopes ranging between $5-15^{\circ}$ over a surface of $1176 \mathrm{~km}^{2}$ (Fig.

$1693 \mathrm{C})$.

170 4.1.3. Favorable soil classes

171 Three major soil classes are recorded in the area: andosols, andic-ferralitic soils and ferralitic soils

172 (Tematio, 2005; Tematio et al., 2009; Tematio et al., 2004) corresponding respectively to andosols,

173 acrisols and ferralsols of the World Reference Base for soil classification (FAO-ISRIC, 2006; Jones et al.,

174 2013). These soils form a toposequence extending from andosols at the upper part of the Bambouto

175 volcano, to acrisols at the middle, and to ferralsols in lower part (Fig. 3D). The B-horizon is well

176 developed except in the andosols of high altitudes where cool climate prevents clay formation and instead

177 favors organo-metal complexes embedding $\mathrm{Al}$ and Fe (Tematio, 2005). This results in the development of

178 a thick organic horizon lying in most cases directly on the bedrock. These andosols are associated on

179 either side of the Mont Bambouto caldera edge with lithosols, which were strongly eroded and reworked

180 out by numerous landslides occurring from the top of the volcano to about $600 \mathrm{~m}$ altitudes westward.

181 Accordingly, only ferralsols and acrisols, which cover 1645 and $131 \mathrm{~km}^{2}$, respectively, are considered for

182 the modeling process.

183

184 4.2. Mapping the bauxitic potential 
Spatial evidences of bauxitic potential were constrained successively from different geological features as described in section 3. First, the maps constrained by elevation and lithology displayed two 187 main areas of bauxite potential, i.e., the northern area made up mainly of the upper surface and the 188 southern area made up mainly of the lower surface (Fig. 6A). The total potential surface at this stage 189 covers $682 \mathrm{~km}^{2}\left(538 \mathrm{~km}^{2}\right.$ and $144 \mathrm{~km}^{2}$ for the upper and the lower surface, respectively). This surface was 190 further constrained with the favorable soil classes, and the resulting surface showed $422 \mathrm{~km}^{2}$ with 291 $191 \mathrm{~km}^{2}$ for the upper surface and $131 \mathrm{~km}^{2}$ for the lower surface. The spatial distribution pattern remains the same as the first potential map, except that the upper surface was reduced in the northern part of the study 193 site (Fig. 6B).

Finally, the map derived from the altitudes, lithology, and soils was further constrained by the slope map that resulted in a predictive bauxitic map characterized by large blank areas with dissected pattern (Fig. 6C) corresponding to slopes ranging from 15 to $76^{\circ}$. The total potential surface is $381 \mathrm{~km}^{2}$, i.e. $19717.2 \%$ of the total studied zone. The slopes of $5-15^{\circ}$ is the most represented $(76 \%)$, showing that the dominant morphological features for bauxite occurrence are the convex shaped summit of elongated 199 interfluves.

\subsection{Validation of the predictive bauxitic laterites map}

As shown in the inference network of Fig. 2, the map of the predictive bauxitic areas was an intermediate step of the modeling process. Comparing this map with data from previous studies and field campaigns was the final step to validate the efficiency of the model for evaluating the accuracy of bauxite mapping. The validation consisted in (i) gathering data from different sources to precisely delineate 206 lateritic duricrusts, and (ii) integrating geochemical data interpolated by kriging to differentiate between 207 ferruginous and bauxitic laterites. The first step in validating the output map was carried out by a rough 208 comparison between the predictive map and the areas with previously studied bauxites deposits such as 209 Fongo-Tongo, Djeu and Loung-Ndoh (Morin, 1985; Nyobe, 1987), Doumbouo-Fokoué (Hiéronymus, 
211 predictive map perfectly matches these areas and highlights a large northern site for which legacy data are

212 still lacking as shown on the figure 6C. Upon validation process, the predictive map delineate a surface of

$21360.1 \mathrm{~km}^{2}$ of lateritic duricrusts on the Bamiléké plateau with $47.8 \mathrm{~km}^{2}$ for the upper surface and $12.3 \mathrm{~km}^{2}$

214 for the lower surface (Fig. 6D).

215 The second step aimed at differentiating between bauxitic laterites and ferruginous laterites. For

216 this purpose, a total of 65 samples randomly distributed in the study area were collected, analyzed for

217 geochemical data (Table. 1) and used for geostatistical analyses. The process of interpolation carried out

218 in this step consisted in determining the distribution of alumina weight percentage on regularly distributed

219 points (pixels) from randomly distributed analytical point values. The output of point interpolation is a

220 raster map, whose pixel values are calculated by interpolation from input point values. The kriging

221 method with a minimum mean interpolation error is currently used (Theodossiou and Latinopoulos,

222 2006). In this study, the kriging process established a spatial correlation between the spatial input values

223 at an optimal lag distance of $1 \mathrm{~km}$. A spherical model fitted to the semi-variogram from this correlation

224 was used as interpolation function. The figure 7 shows the kriging map differentiating three main

225 geochemical areas. The first area is characterized by highest alumina values, confined on the upper

226 surface (comprising localities of Fongo-Tongo, Djeu, Loung-Ndoh and Bangam). The geochemical trends

227 are represented with alumina values decreasing from Fongo-Tongo to Djeu on the western part of the

228 lateritic map, and on the eastern part with a slight increasing trend toward the SE (Bangam). These areas

229 display interpolated alumina values extending from 44 up to 66 wt. $\% \mathrm{Al}_{2} \mathrm{O}_{3}$. The second area is 230 delineated in the southern part of the lower surface at Fokoué and Sa, where alumina values extend from 23140 to 44 wt.\% $\mathrm{Al}_{2} \mathrm{O}_{3}$ with a slight decrease northward (Fig. 7). The third area is confined to the 232 Doumbouo region where ferruginous laterites are characterized by alumina content less than 40 wt.\%, 233 varying from 39 to 13 wt.\% $\mathrm{Al}_{2} \mathrm{O}_{3}$. The total bauxitic-rich surface of the Bamiléké plateau is then of 56.2 $234 \mathrm{~km}^{2}$, while ferruginous laterites cover a surface of $3.9 \mathrm{~km}^{2}$. 


\section{Discussion}

\subsection{Spatial features evidence and predictive map of bauxite potential}

The Boolean model applied in this study has resulted in an $82.8 \%$ reduction in the potential bauxite area to be considered. The predictive map has indicated that the bauxite potential covers $17.2 \%$ of the total study area, that perfectly matches known areas of bauxite deposits as derived from previous studies on the Bamiléké plateau (Hiéronymus, 1973; Momo Nouazi et al., 2012; Morin, 1985; Nyobe, 1987). Out of the $17.2 \%$ bauxite potential from the predictive map, the total confirmed bauxitic area of the Bamiléké plateau derived from validation steps only covers about 3\% of the total investigated area $243\left(56.1 \mathrm{~km}^{2}\right)$. This reduced bauxitic surface can be explained by (i) the advanced stage of bauxitic landsurface dismantling (Momo Nouazi et al., 2012), which induces the total stripping of duricrust on interfluves with favorable genetic characteristics (rock and soil) and favorable morphological criteria; and (ii) the flat and gently sloped areas in the northern part of the predictive map covered by unaltered basaltic

247 and trachytic flows. This methodology allows a regional scale evaluation of lateritic bauxites by highlighting the low preservation and increasing dismantling of these lateritic surfaces, which had already been noticed all over the remnants of the planation surfaces (see Momo-Nouazi et al., 2012). The criteria used in this study are quite similar to those used by Carranza (2002) for determining the predictive map of

251 nickeliferous-laterites of the Isabela area in Philippines. The resulting map demonstrated the reliability of 252 the method in large areas with a limited number of mineral prospects. It is thus a relatively effective, 253 rapid, and cheap approach, which can be applied to assess a large number of mineral potential as 254 described by Bonham-Carter (1994). It can then be considered as a promising approach applicable to 255 other bauxitic regions of Cameroon such as the Adamaoua bauxitic landsurfaces with wide duricrusted 256 and gently sloped plateaus $\left(\leq 2^{\circ}\right)$ developed on volcanic rocks (Eno Belinga, 1966; Vicat and Bilong, 257 1998) for a larger scale spatial regionalization. 
Bauxites of the Bamiléké plateau are distributed in five main spots named Bangam, Doumbouo-

261 Fokoué, Fongo-Tongo, Loung-Ndoh and Djeu with respectively $39.87 \mathrm{~km}^{2}, 8.44 \mathrm{~km}^{2}, 4.52 \mathrm{~km}^{2}, 1.78 \mathrm{~km}^{2}$

262 and $1.59 \mathrm{~km}^{2}$. They contain essentially $40-66 \mathrm{wt} . \%$ of alumina that is less than those of Minim-Martap

$263(45-75 \mathrm{wt} \%)$ but more than those of Ngaoundal-Ngaoundourou (46-48 wt.\%) in the Adamaoua region

264 (Eno Belinga, 1966; Vicat and Bilong, 1998). The total bauxite reserve of the Bamiléké plateau is still not

265 quantified. However, some attempts based on (i) thickness data from limited number of pits and (ii)

266 surface evaluation by contouring have been performed on the Fongo-Tongo and the Doumbouo-Fokoué

267 spots with 46 million tons (Hiéronymus, 1973) and 9 million tons (Momo Nouazi et al., 2012),

268 respectively. These values are lower than those of the Adamaoua region of Cameroun. The Bangam spot

269 revealed by this study with the largest $\left(39.9 \mathrm{~km}^{2}\right)$ and richest bauxitic ore (45-66 wt.\% alumina) has

270 unfortunately not been evaluated so far. Further researches on vertical extent of bauxite in this spot are

271 thus highly recommended here.

272

273

\section{Summary and conclusion}

This study has suitably combined spatial multisource data to define potential bauxitic laterites

275 distribution on the Bamiléké plateau, and evaluate the usefulness of including field observations, and

276 geochemical data processed by statistical method for improving the mineral mapping process. Genetic

277 criteria and a regolith landform model were successfully used to predict and precisely delineate areas of

278 bauxite occurrence, thereby highlighting a total bauxitic-rich surface of $56.2 \mathrm{~km}^{2}$. The alumina content of

279 these duricrusts is quite high, but the large spatial distribution into five spots may render their bauxitic

280 exploitation quite expensive. However, results of this study can be considered as an important input into

281 the assessment and classification of lateritic ores in Cameroon.

282 At the national-wide level, the bauxitic laterites potential has not yet been fully assessed. Using

283 the approach developed in this study, the bauxite potential for the entire country could be achieved much

284 more cheaply than the traditional methods. The whole Cameroon volcanic line with deep weathered and 
286 study.

\section{Acknowledgement}

The financial support for geochemical data of this study was provided by the SCAC (Service de

Coopération et d'Action Culturelle de la France au Cameroun). The geochemical analysis have been

carried out at the Centre Européen de Recherche et d'Enseignement des Géosciences de l'Environnement (CEREGE), Aix Marseille University, OSU Pytheas, France.

\section{References}

Ballentine, C.J., Lee, D.C., Halliday, A.N., 1997. Hafnium isotopic studies of the Cameroon Line and new HIMU paradoxes. Chemical Geology 139, 111-124.

Beauvais, A., Chardon, D., 2013. Modes, tempo, and spatial variability of Cenozoic cratonic denudation: The West African example. Geochemistry, Geophysics, Geosystems 14(5), 1590-1608. doi:10.1002/ggge.20093.

Bildgen, P., 1973. Contribution à l'étude de la genèse et de l'évolution des bauxites karstiques de Provence: géologie, minéralogie, géochimie des formations bauxitiques des Alpilles. Doctorat 3ème cycle, Paris, 134 pp.

Bonham-Carter, G.F., 1994. Geographic Information Systems for Geoscientists. Modeling with GIS. First ed. Pergamon, New York.

Boroushaki, S., Malczewski, J., 2008. Implementing an extension of the analytical hierarchy process using ordered weighted averaging operators with fuzzy quantifiers in ArcGIS. Computers \& Geosciences 34(4), 399-410. 
Boulangé, B., 1984. Les formations bauxitiques latéritiques de Côte d’Ivoire. Les faciès, leur transformation, leur distribution et l'évolution du modelé. Thèse et Mémoire ORSTOM, 363 pp.

Boulangé, B., Ambrosi, J.-P., Nahon, D., 1997. Laterites and Bauxites. In: H. Paquet and N. Clauer (Editors), Soils and Sediments : mineralogy and geochemistry. Springer Berlin Heidelberg, pp. $49-65$

Boulangé, B., Bouzat, G., Pouliquen, M., 1996. Mineralogical and geochemical characteristics of two bauxite profiles, Fria, Guinea Republic. Mineral Deposita 31, 432-438.

Boulangé, B., Colin, F., 1994. Rare earth element mobility during conversion of nepheline syenite into lateritic bauxite at Passa Quatro, Minais Gerais, Brazil. Applied geochemistry 9, 701-711.

Carranza, E.J.M., 2002. Geologically-Constrained Mineral Potential Mapping (Examples from the Philippines). Ph.D. Thesis Thesis, International Institute for Geo-Information Science and Earth Observation, Enschede, 480 pp.

Carranza, E.J.M., 2009. Geochemical anomalies and mineral prospectivity mapping in GIS., Hanbook of exploration and environmental geochemistry pp. 351.

Carranza, E.J.M., Mangaoang, J.C., Hale, M., 1999. Application of mineral exploration models and GIS to generate mineral potential maps as input for optimum land-use planning in the Philippines. Natural Resources Research 8(2), 165-173.

Carranza, E.J.M., van Ruitenbeek, F.J.A., Hecker, C., van der Meijde, M., van der Meer, F.D., 2008. Knowledge-guided data-driven evidential belief modeling of mineral prospectivity in Cabo de Gata, SE Spain. International Journal of Applied Earth Observation and Geoinformation 10(3), 374-387. 
Chardon, D., Chevillotte, V., Beauvais, A., Grandin, G., Boulangé, B., 2006. Planation, bauxites and epeirogeny: One or two paleosurfaces on the West African margin? Geomorphology 82, 273-282. doi:210.1016/j.geomorph.2006.1005.1008.

Cheng, Q., Agterberg, F.P., 1999. Fuzzy weights of evidence and its application in mineral potential mapping. Natural Resources Research 8 (1), 27-35.

De Araújo, C.C., Macedo, A.B., 2002. Multicriteria Geologic Data Analysis for Mineral Favorability Mapping: Application to a Metal Sulphide Mineralized Area, Ribeira Valley Metallogenic Province, Brazil. Natural Resources Research 11(1), 29-43.

Déruelle, B., Moreau, C., Nkoumbou, C., Kambou, R., Lissom, J., Njonfang, E., Ghogomu, R.T., Nono, A., 1991. The Cameroon Line: a review. In: A.B. Kampunzu, R.T. Lubala (Eds.), Magmatism in extensional structural settings. The Phanerozoic African Plate. Springer, Berlin, pp. 274-327.

Dumort, J.C., 1968. Carte géologique de reconnaissance au 1/500.000. . imprimerie Nationale, D.M.G. Yaoundé, .

Eno Belinga, S.M., 1966. Contribution à l'étude géologique, minéralogique et géochimique des formations bauxitiques de l'Adamaoua (Cameroun) Doctorat de Troisième Cycle, Université de Paris, Paris 155 pp.

Eno Belinga, S.M., 1968. Etude pétrographique des bauxites de Ngaoundal et de Minim-Martap dans l’Adamaoua (Cameroun). Annales de la Faculté des Sciences 1, 55-68.

Eno Belinga, S.M., 1972. L'altération des roches basaltiques et le processus de bauxitisation dans l'Adamaoua (Cameroun). Doctorat d'Etat, Université Paris, Paris, 571 pp.

FAO-ISRIC, 2006. World Reference Base for Soil Resources FAO, Rome.

Grandin, G., Thiry, M., 1983. Les grandes surfaces continentales tertiaires des régions chaudes. Succession des types d'altération. Cahier ORSTOM, série Géologie 13(1), 3-18. 
Guha, A., Singh, V.K., Parveen, R., Vinod Kumar, K., Jeyaseelan, A.T., Dhanamjaya Rao, E.N., 2013. Analysis of ASTER data for mapping bauxite rich pockets within high altitude lateritic bauxite, Jharkhand, India. International Journal of Applied Earth Observation and Geoinformation 21, 184-194.

Harris, J.R., Lemkow, D., Jefferson, C., Wright, D., Falck, H., 2008. Mineral Potential Modelling for the Greater Nahanni Ecosystem Using GIS Based Analytical Methods. Natural Resources Research 17(2), 51-78.

Harris, J.R., Wilkinson, L., Heather, K., Fumerton, S., Bernier, M.A., Ayer, J., Dahn, R., 2001. Application of GIS processing techniques for producing mineral prospectivity maps - a case study: mesothermal Au in the Swayze Greenstone Belt, Ontario, Canada. Natural Resources Research 10(2), 91-124.

Hiéronymus, B., 1973. Etude minéralogique et géochimique des formations bauxitiques de l'ouest Cameroun. Doctorat 3e Cycle, Univ. Paris VI, Paris, 98 pp.

Hodgson, C.J., 1990. Uses (and abuses) of ore deposit models in mineral exploration. Geoscience Canada 17(2), 79-89.

ITC ILWIS Unit, 2001. ILWIS 3.0 Academic user's guide. ITC, Enschede, NL, pp. 520.

Jones, A., Breuning-Madsen, H., Brossard, M., Dampha, A., Deckers, J., Dewitte, O., Gallali, T., Hallett, S., Jones, R., Kilasara, M., Le Roux, P., Micheli, E., Montanarella, L., Spaargaren, O., Thiombiano, L., Van Ranst, E., Yemefack, M. , Zougmor. R., (eds.), 2013. Soil Atlas of Africa. European Commission, Publications Office of the European Union, Luxembourg. 176 pp.

Kagou Dongmo, A., Nkouathio, D., Pouclet, A., Bardintzeff, J.-M., Wandji, P., Nono, A., Guillou, H., 2010. The discovery of Late Quaternary basalt on Mount Bambouto: implications for recent 
widespread volcanic activity in the southern Cameroon Line. Journal of African Earth Sciences 57, 96-108.

Kwekam, M., Liégeois, J.P., Njonfang, E., Affaton, P., Hartmann, G., 2010. Nature, Origin and Significance of the Fomopéa Pan-African High-K Calc-alkaline Plutonic Complex in the Central African Fold Belt (Cameroon) Journal of African Earth Sciences 57, 79-95.

Maignien, R., 1966. Compte rendu de recherche sur les laterites. Col. Rech. Rers. Nat. UNESCO, Paris 4.

Marzoli, A., Renne, P.R., Piccirillo, E.M., Francesca, C., Bellieni, G., Melfi, A.J., Nyobe, J.B., N'ni, J., 1999. Silicic magmas from the continental Cameroon volcanic line (Bambouto and Ngaoundéré): 40Ar/39Ar dates, petrology, Sr-Nd-O isotopes and theirpetrogenetic significance. Contrib. Mineral. Petrol. 135, 133-150.

Momo Nouazi, M., Tematio, P., Yemefack, M., 2012. Multiscale organization of the Doumbouo-Fokoué Bauxites Ore Deposits (West Cameroun): Implication to the Landscape Lowering. Open Journal of Geology 2, 14-24.

Morin, S., 1985. Cuirasses et reliefs de l'ouest Cameroun, Laboratoire de géomorphologie du CEGET/CNRS, 33405 Talence, France.

Nicolas, J., Eno Belinga, S.M., 1969. Contribution à l'étude de l'origine et de l'évolution des bauxites de l'Adamaoua (Cameroun). C. R. Ac. SC. Paris, série D, 268, 1157-1160.

Nkouathio, D.G., 2006. Evolution tectono-magmatique et volcanologique de la Ligne du Cameroun: comparaison d'un volcanisme de graben (plaine de Tombel) et d'un volcanisme de horst (monts Bambouto). Thèse Doctorat Thesis, Université Yaoundé-1, Yaounde, Cameroun, 231 pp.

Nkouathio, D.G., Kagou, D.A., Bardintzeff, J.M., Wandji, P., Bellon, H., Pouclet, A., 2008. Evolution of volcanism in graben and horst structures along the Cenozoic Cameroon Line (Africa): implications for tectonic evolution and mantle source composition. Min. Pet. 94, 287-303. 
Ntép Gweth, P., 2009. Ressources minérales des arrondissements de la région de l'Ouest. Extrait de la carte thématique de ressources minérales du Cameroun sur un fond géologique (2001).

Nyobe, J.B., 1987. A geological and geochemical study of the Fongo-Tongo and areally related bauxites deposits, Wersten Highlands, Republic of Cameroun. PhD thesis, $352 \mathrm{pp}$.

Pedro, C., 1968. Distribution des principaux types d'altérations à la surface du globe. Présentation d'une esquisse géographique. Revue Géogr. Phys. Géol. Dyn. 10(5), 457-470.

Reeves, C.V., Westerhof, A.B., Botman, L.G., Dessauvagie, T.F.J., Dijkstra, S., 1990. Systematic mineral resource development in the '90s and the next century: new techniques, old challenges. ITC Journal 2, 92-101.

Riis, F., Fjeldskaar, W., 1992. On the magnitude of the late Tertiary and Quaternary erosion and its significance for the uplift of Scandinavia and the Barents sea. In: R.M. Larsen, H. Brekke, B.T. Larsen, E. Talleras (Eds.), Structural and tectonic modeling and its application to petroleum geology. NPF Special Publications 1, Elsevier Amsterdam, pp. 163-185.

Robinove, C.J., 1989. Principles of logic and the use of digital geographic information systems. In: W.J. Ripple (Ed.), Fundamentals of Geographic Information Systems, a Compendium. American Society for Photogrammetry and Remote Sensing, pp. 112-124.

Segalen, D., 1967. Les sols et la géomorphologie du Cameroun Cahier ORSTOM, Sér. Pédologie 5(2), 137-187.

Soler, J.M., Lasaga, A.C., 2000. The Los Pijiguaos bauxite deposit (Venezuela): A compilation of field data and implications for the bauxitization process Journal of South American Earth Sciences 13, 47-65.

Tardy, Y., 1993. Pétrologie des latérites et des sols tropicaux. Masson, Paris. 
Tematio, P., 2005. Etude cartographique et pétrographique des sols à caractères ferralitiques et andosoliques dans lesmonts Bambouto (Ouest Cameroun): influence de la nature lithologique et des facteurs du milieu sur la nature et la distribution des sols en regions de montagne tropicale humide. Doctorat d'Etat Thesis, Univ. Yaoundé I, Yaounde, 251 pp.

Tematio, P., Fritsch, E., Hodson, M.E., Lucas, Y., Bitom, D., Bilong, P., 2009. Mineral and geochemical characterization of a leptic-aluandic soil and athapto-aluandic-ferralsol developed on trachytes in Mount Bambouto (Cameroon volcanic line). Geoderma 152, 314-323.

Tematio, P., Kengni, L., Bitom, D., Hodson, M., Fopoussi, J.C., Leumbe, O., Mpakam, H.G., Tsozué, D., 2004. Soils and their distribution on Bambouto volcanic mountain, West Cameroon highland, Central Africa. Journal of African Earth Sciences. 39, 447-457.

Theodossiou, N., Latinopoulos, P., 2006. Evaluation and optimization of ground water observation network using the Kriging methodology. Environmental modeling and software 21, 991-1000.

Thiart, C., De Wit, M., 2000. Linking spatial statistics to GIS: exploring potential gold and tin models of Africa. South African Journal of Geology 103(3-4), 215-230.

Thole, U., Zimmermann, H.-J., Zysno, P., 1979. On the suitability of minimum and product operators for intersection of fuzzy sets. Fuzzy Sets and Systems 2(3), 167-180.

Tsopjio Jiomeneck, S.P., Tematio, P., Wilson, A., Yemefack, M., 2011. Andosolization of Soils on a Strombolian Cone at Mount Bambouto, Cameroon. Open Journal of Soil Science 1, 97-105.

Varnes, D.J., 1974. The logic of geological maps, with reference to their interpretation and use for engineering purposes. United States Geological Survey Professional Paper 837.

Vicat, J.-P., Bilong, P., 1998. Géosciences au Cameroun. Presses Universitaires de Yaoundé.

Zadeh, L.A., 1965. Fuzzy sets. IEEE Information and Control 8 (3), 338-353. 


\begin{tabular}{|c|c|c|c|c|c|c|c|c|c|}
\hline \multirow{2}{*}{\multicolumn{2}{|c|}{$\frac{\text { Lower surface }}{\text { Doumbouo-Fokoué }}$}} & \multicolumn{8}{|c|}{ Upper surface } \\
\hline & & \multicolumn{2}{|c|}{ Fongo-Tongo } & \multicolumn{2}{|c|}{ Bangam } & \multicolumn{2}{|c|}{ Loung } & \multicolumn{2}{|r|}{ Djeu } \\
\hline Sample & $\mathrm{Al}_{2} \mathrm{O}_{3}(\mathrm{wt} \%)$ & Sample & $\mathrm{Al}_{2} \mathrm{O}_{3}(\mathrm{wt} \%)$ & Sample & $\mathrm{Al}_{2} \mathrm{O}_{3}(\mathrm{wt} \%)$ & Sample & $\mathrm{Al}_{2} \mathrm{O}_{3}(\mathrm{wt} \%)$ & Sample & $\mathrm{Al}_{2} \mathrm{O}_{3}(\mathrm{wt} \%)$ \\
\hline DF1 & 31.3 & FO1 & 50.8 & BA1 & 51.1 & LO1 & 57.3 & DJ1 & 22.3 \\
\hline DF2 & 35.1 & $\mathrm{FO} 2$ & 59.7 & BA2 & 47.1 & $\mathrm{LO} 2$ & 39.1 & $\mathrm{DJ} 2$ & 27.2 \\
\hline DF3 & 52.6 & FO3 & 34.0 & BA3 & 48.4 & LO3 & 54.7 & DJ3 & 28.9 \\
\hline DF4 & 38.7 & FO4 & 43.1 & BA4 & 38.4 & LO4 & 44.3 & DJ4 & 47.3 \\
\hline DF5 & 37.6 & FO5 & 44.4 & BA5 & 38.3 & LO5 & 53.7 & DJ5 & 40.0 \\
\hline DF6 & 42.0 & FO6 & 47.2 & BA6 & 60.3 & LO6 & 46.9 & DJ6 & 35.2 \\
\hline DF7 & 44.5 & FO7 & 49.4 & BA7 & 60.4 & LO7 & 54.9 & DJ7 & 38.4 \\
\hline DF8 & 28.7 & FO8 & 51.6 & BA8 & 59.7 & & & & \\
\hline DF9 & 35.9 & FO9 & 48.2 & BA9 & 46.8 & & & & \\
\hline DF10 & 36.0 & FO10 & 37.4 & BA10 & 43.5 & & & & \\
\hline DF11 & 35.0 & FO11 & 44.0 & BA11 & 42.8 & & & & \\
\hline DF12 & 47.5 & FO12 & 49.8 & BA12 & 40.0 & & & & \\
\hline DF13 & 49.5 & FO13 & 57.5 & BA13 & 47.3 & & & & \\
\hline DF14 & 36.0 & FO14 & 44.9 & & & & & & \\
\hline DF15 & 33.3 & FO15 & 50.1 & & & & & & \\
\hline DF16 & 37.7 & FO16 & 49.9 & & & & & & \\
\hline DF17 & 13.8 & FO17 & 39.3 & & & & & & \\
\hline
\end{tabular}



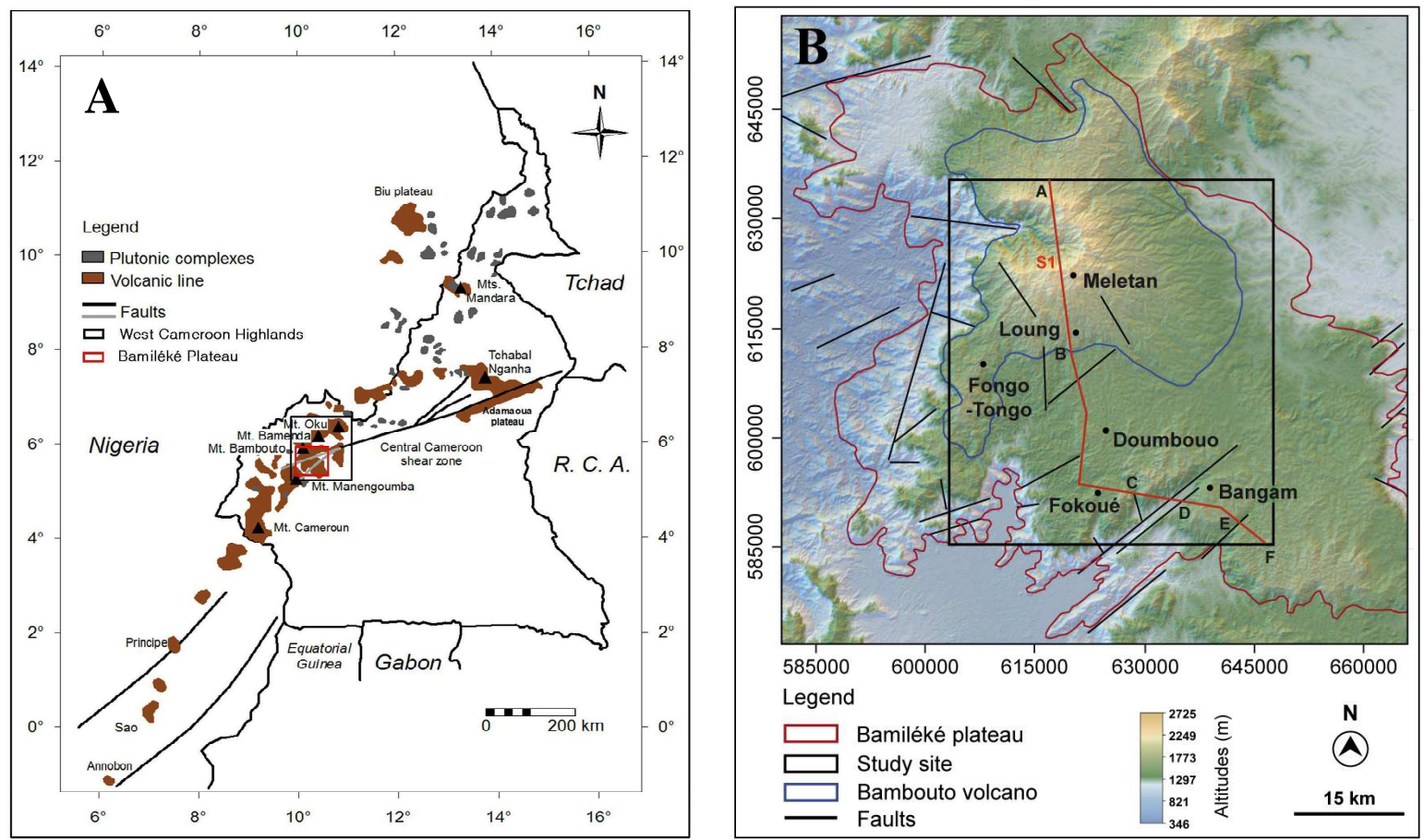

Figure 1. A: Localization and structure of the Cameroon volcanic line (from Ballentine et al., 1997; and Ngako et al., 2006); B: morphology of the Bamiléké plateau. Letters A to F mark the major morphological changes along the cross section in figure 4 . 

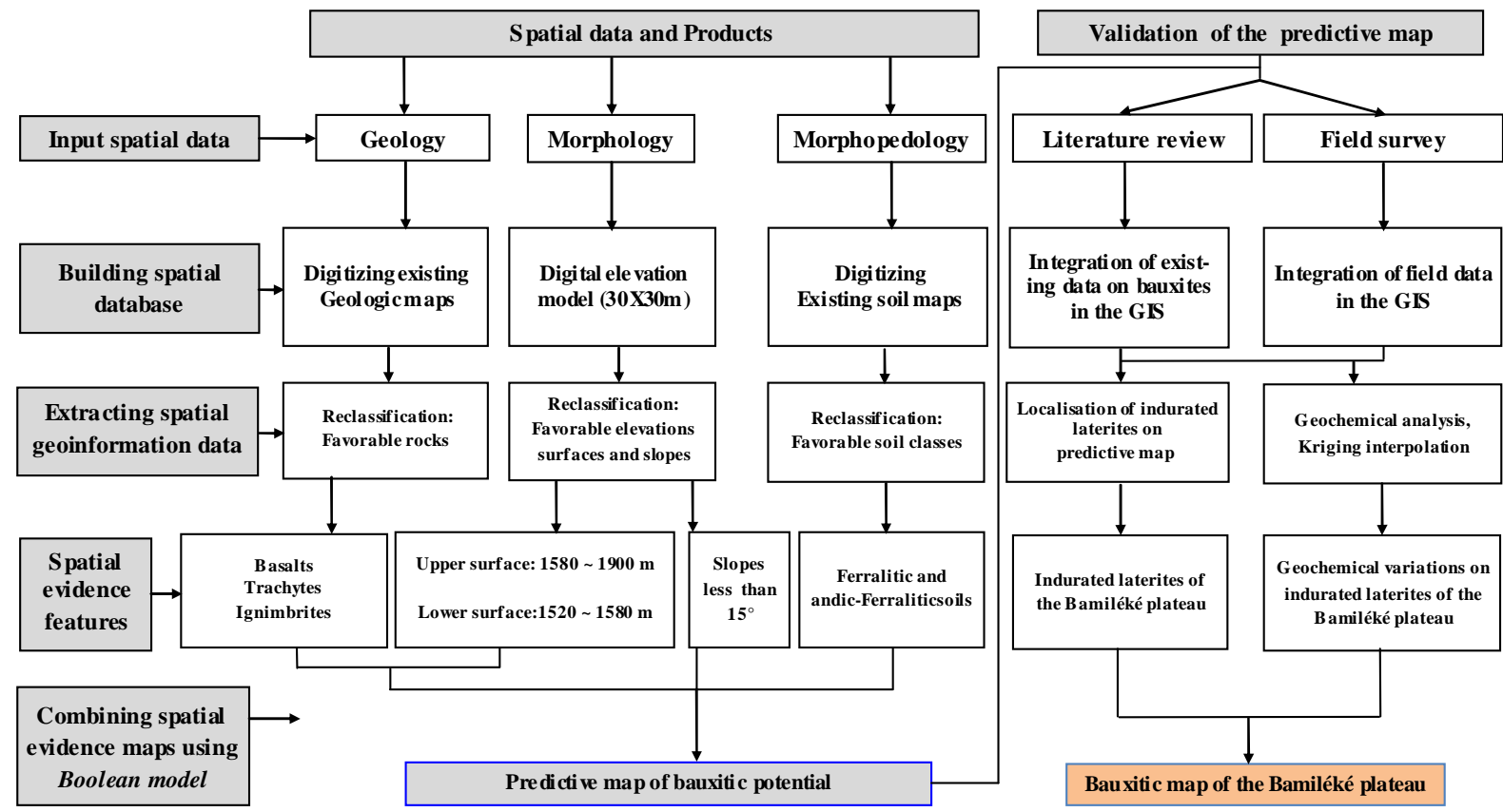

Figure 2. Methodology applied to undertake geologically constrained mapping of the Bamiléké plateau bauxites 

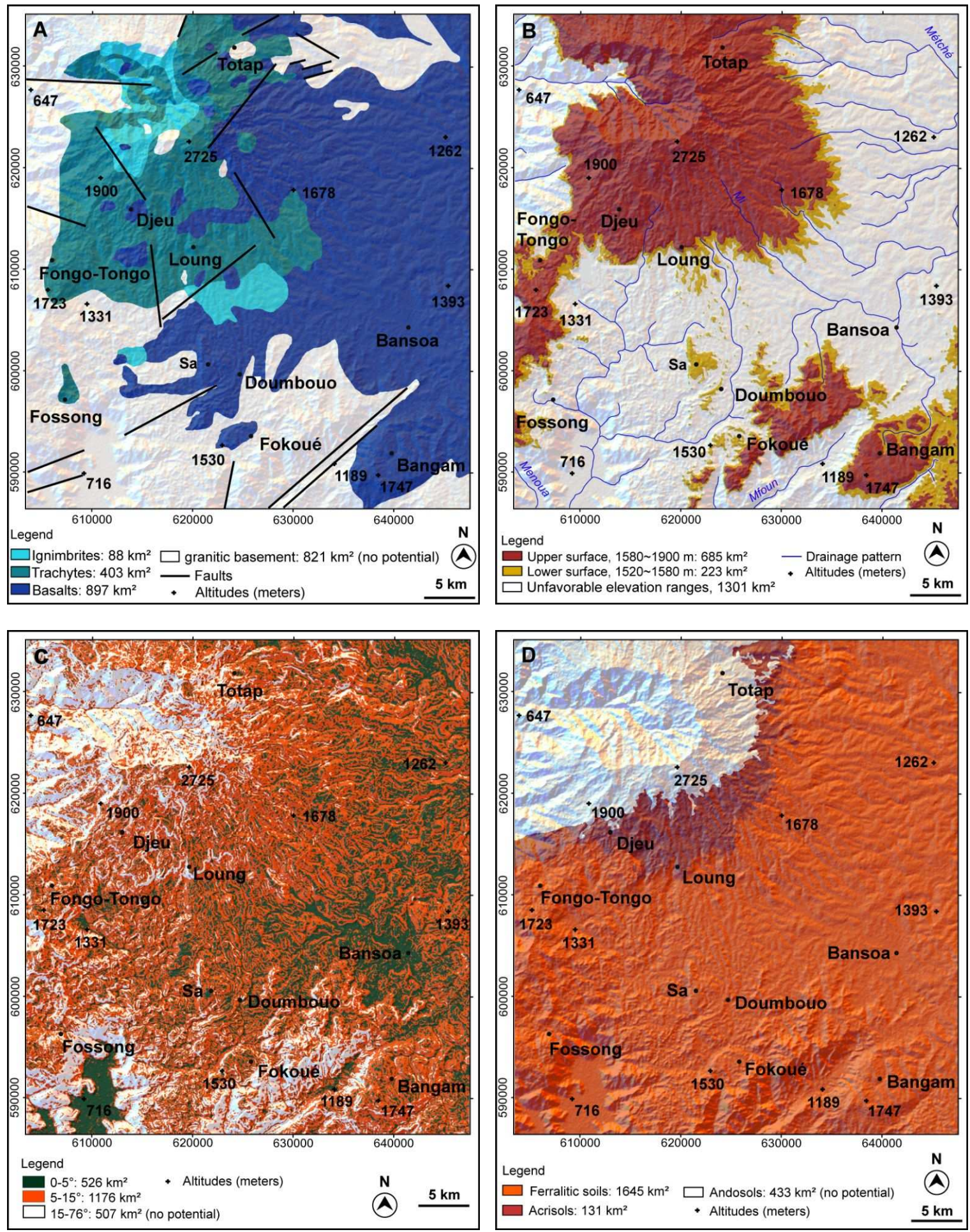

Figure 3. Favorable constraints maps. A: rocks; B: elevation ranges; C: slopes; D: soil 
Figure 4

456

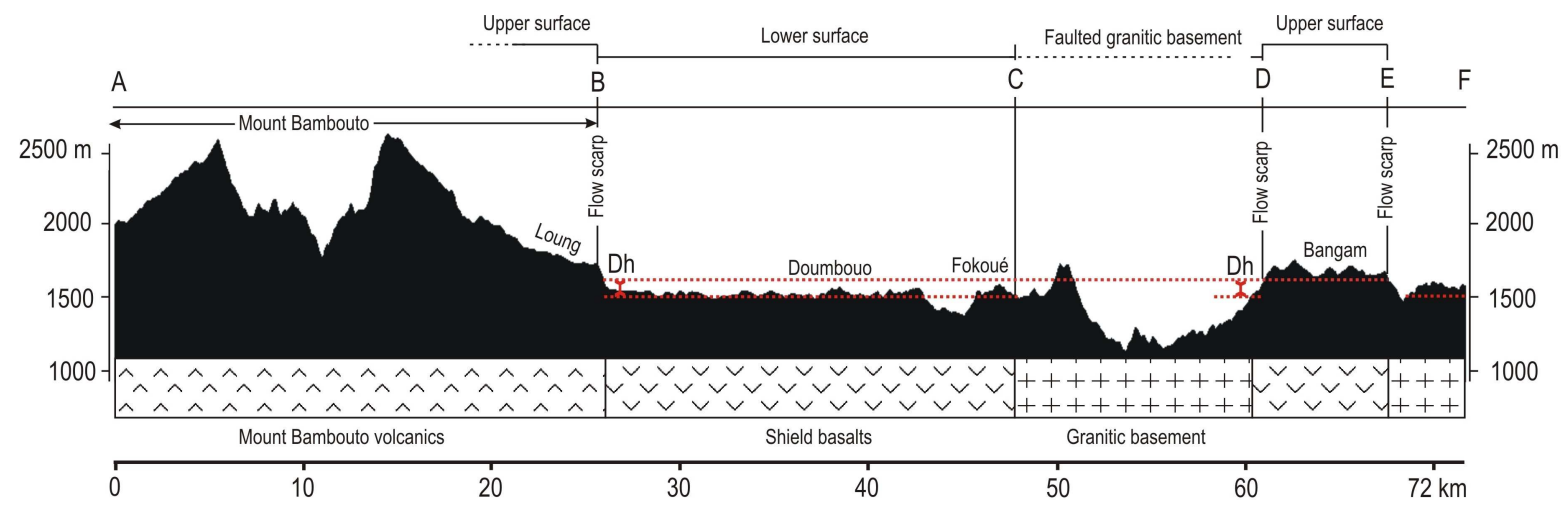

458

Figure 4. Cross section showing the vertical and lateral distribution of lateritic surfaces. Section S1 on figure 1B

459 
Figure 5

460

461

462

463

464
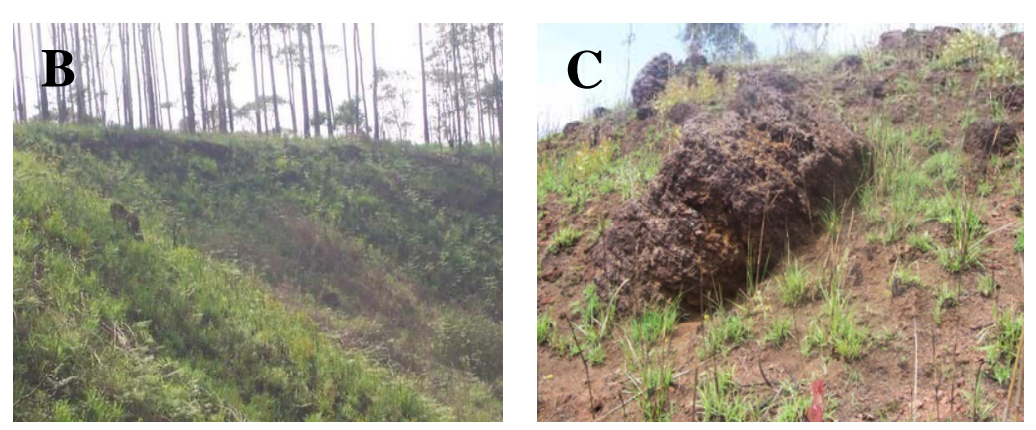

Figure 5. Morphological distribution of duricrust on the Bamiléké plateau. A: continuous duricrust on flat interfluves; B: steep slope limiting flat duricrust on the top; C: convex slope showing evidence of duricrust dismantling

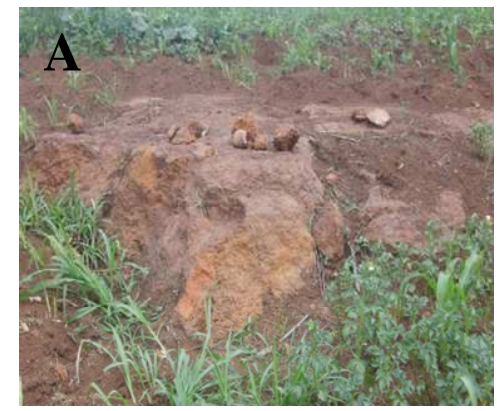



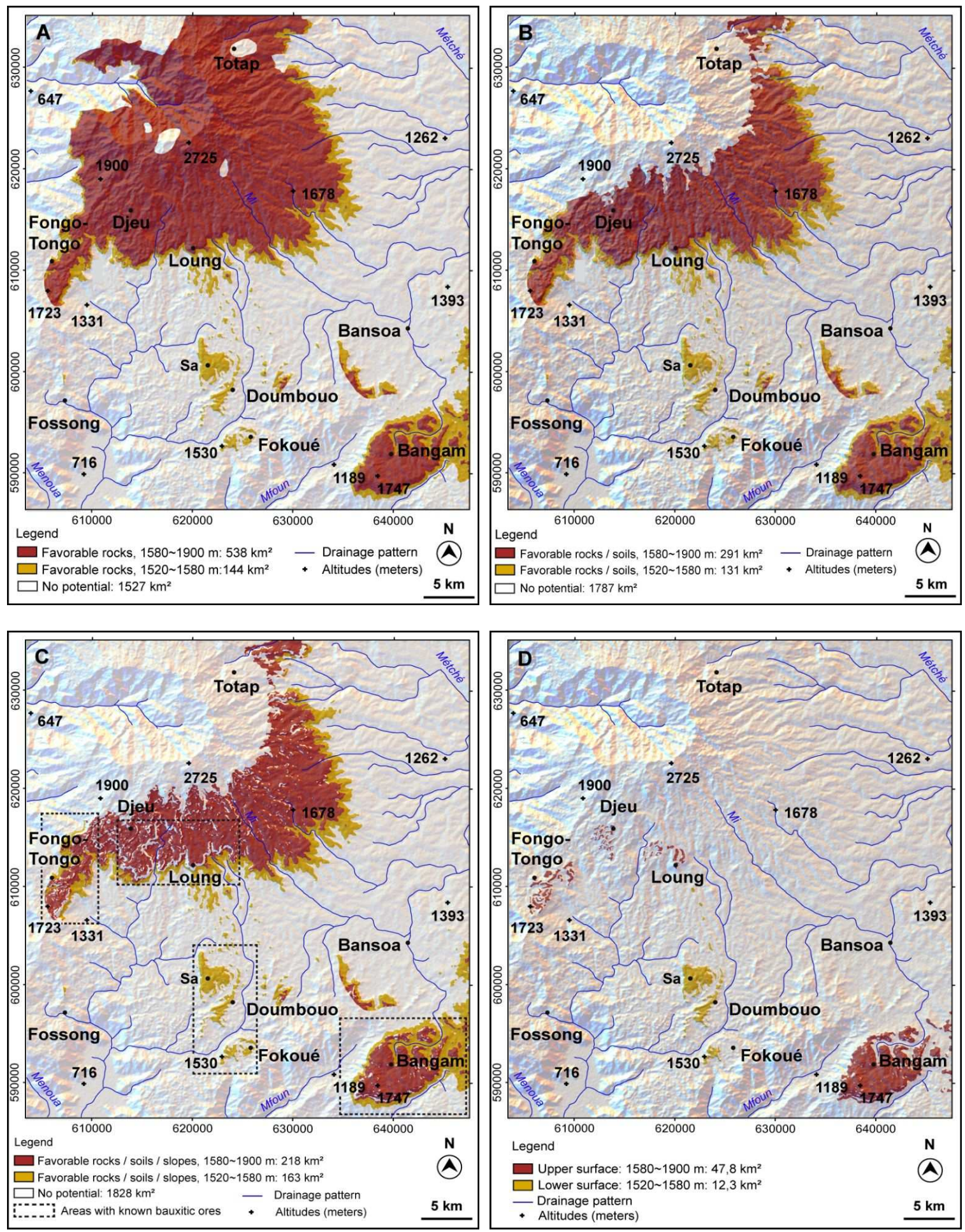

Figure 6. Potential maps and field validation results. A: favorable elevation ranges constrained with favorable rock types; B: A constrained with favorable soil classes; C: B constrained with favorable slopes; D: map of indurated laterites of the Bamiléké plateau. 


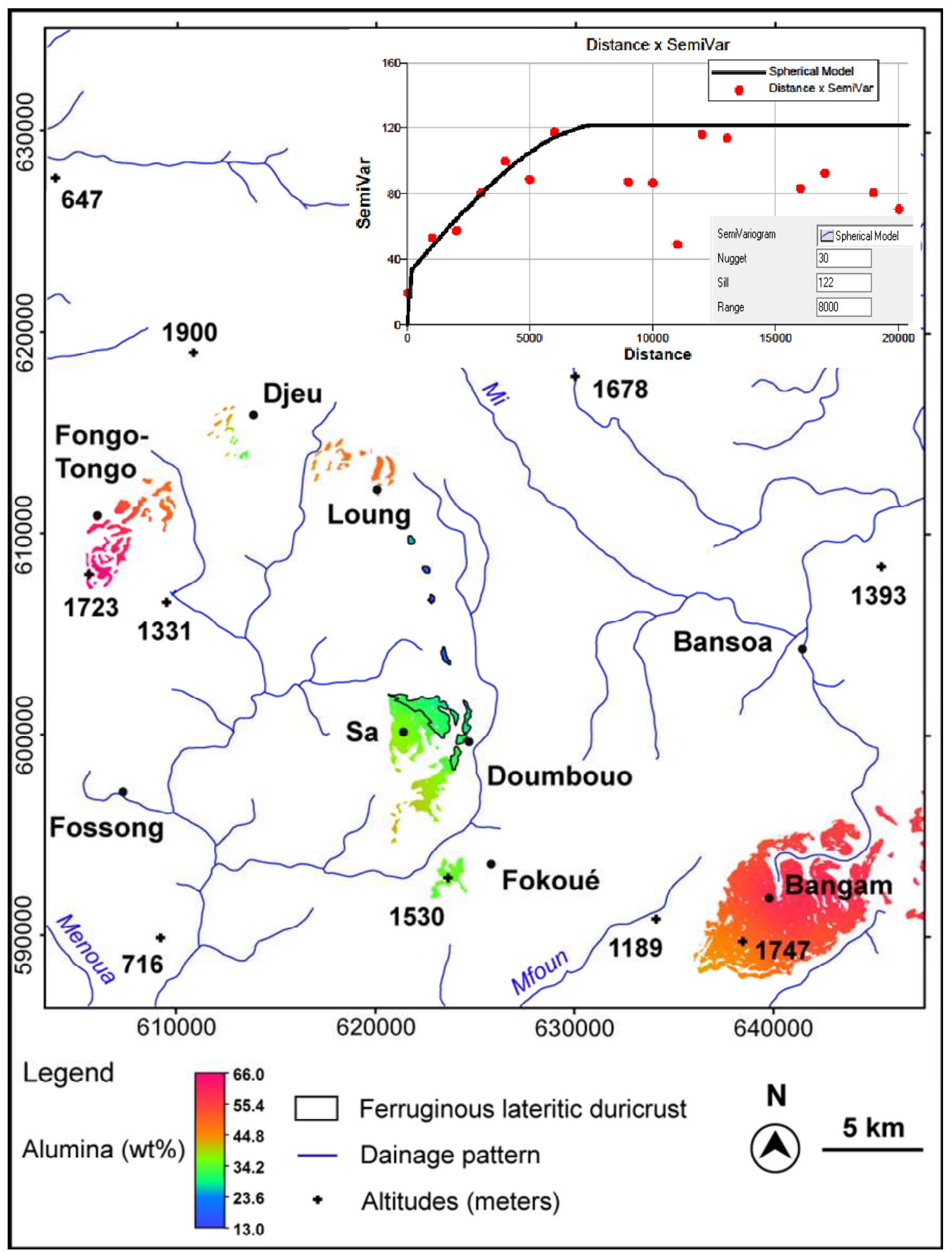

471 Figure 7. A: Semi-variogram model; B: map showing the distribution of alumina percentages on indurated laterites 472 of the Bamiléké plateau 